\title{
Recent advances in the molecular mechanisms determining tissue sensitivity to glucocorticoids: novel mutations, circadian rhythm and ligand- induced repression of the human glucocorticoid receptor
}

\author{
Nicolas C Nicolaides ${ }^{1,2^{*}}$, Evangelia Charmandari ${ }^{1,2}$, George P Chrousos ${ }^{1,2,3}$ and Tomoshige Kino ${ }^{4}$
}

\begin{abstract}
Glucocorticoids are pleiotropic hormones, which are involved in almost every cellular, molecular and physiologic network of the organism, and regulate a broad spectrum of physiologic functions essential for life. The cellular response to glucocorticoids displays profound variability both in magnitude and in specificity of action. Tissue sensitivity to glucocorticoids differs among individuals, within tissues of the same individual and within the same cell. The actions of glucocorticoids are mediated by the glucocorticoid receptor, a ubiquitously expressed intracellular, ligand-dependent transcription factor. Multiple mechanisms, such as pre-receptor ligand metabolism, receptor isoform expression, and receptor-, tissue-, and cell type-specific factors, exist to generate diversity as well as specificity in the response to glucocorticoids. Alterations in the molecular mechanisms of glucocorticoid receptor action impair glucocorticoid signal transduction and alter tissue sensitivity to glucocorticoids. This review summarizes the recent advances in our understanding of the molecular mechanisms determining tissue sensitivity to glucocorticoids with particular emphasis on novel mutations and new information on the circadian rhythm and ligand-induced repression of the glucocorticoid receptor.
\end{abstract}

Keywords: Glucocorticoid receptor, Glucocorticoid resistance, Glucocorticoid hypersensitivity, Glucocorticoid signal transduction

\section{Background}

In humans, glucocorticoids are synthesized by the adrenal cortex and released following activation of the hypothalamic-pituitary-adrenal (HPA) axis, and play an important role in the maintenance of resting and stressrelated homeostasis. Named for their effects on glucose metabolism, glucocorticoids are involved in almost every cellular, molecular and physiologic network of the organism, and regulate a broad spectrum of physiologic

\footnotetext{
* Correspondence: nnicolaides@bioacademy.gr

'Division of Endocrinology, Metabolism and Diabetes, First Department of Pediatrics, University of Athens Medical School, 'Aghia Sophia' Children's Hospital, Athens 11527, Greece

${ }^{2}$ Division of Endocrinology and Metabolism, Clinical Research Center, Biomedical Research Foundation of the Academy of Athens, Athens 11527, Greece

Full list of author information is available at the end of the article
}

functions essential for life, including growth, reproduction, cognition, behavior, cell proliferation and survival, as well as immune, central nervous system (CNS) and cardiovascular functions [1-3]. Given their powerful antiinflammatory and immunosuppressive actions, synthetic glucocorticoids represent one of the most widely used therapeutic compounds employed in the treatment of acute and chronic inflammatory/autoimmune and lymphoproliferative disorders $[1,3]$. However, chronic exposure to glucocorticoids in patients with such disorders leads to multiple adverse effects. Sometimes glucocorticoid resistance of the affected organ or tissue may develop, representing a major challenge for the treatment of these conditions [4].

At the cellular level, the actions of glucocorticoids are mediated by the human glucocorticoid receptor 
( $h G R, N R 3 C 1$ ), which belongs to the steroid/thyroid/ retinoic acid nuclear receptor superfamily of transcription factors $[2,5]$. Consistent with the pleiotropic effects of glucocorticoids, the hGR is ubiquitously expressed in all human tissues and cells, and is necessary for life after birth [6]. The hGR protein is encoded by exons 2-9 of the $h G R$ gene (located on chromosome 5) and is composed of four distinct regions: the amino-terminal domain (NTD), the DNA-binding domain (DBD), the hinge region and the ligand-binding domain (LBD) [2,5]. Alternative splicing of hGR precursor mRNA gives rise to 5 hGR protein subtypes that have been termed $h G R \alpha$, hGR $\beta$, hGR $\gamma$, hGR-A and hGR-P. An additional cohort of eight receptor proteins (hGR $\alpha-A$, hGR $\alpha-B$, hGR $\alpha-C 1$, hGR $\alpha-C 2$, hGR $\alpha-C 3$, hGR $\alpha-D 1$, hGR $\alpha-D 2$, and hGR $\alpha-D 3$ ) is produced by alternative translation initiation from hGR mRNA [2,5,7]. hGR $\alpha$-A is the classic full-length 777-amino acid receptor that is generated from the first translation initiation codon [2,5,7]. The other hGR $\alpha$ isoforms have progressively shorter NTDs, possess both common and unique properties and may differentially transduce the glucocorticoid signal to target tissues depending on their selective relative expression and inherent activities. All translational isoforms have similar affinity for the ligand and ability to bind to DNA, consistent with the presence of a common LBD. However, they display differences in their subcellular distribution, with $\mathrm{hGR} \alpha-\mathrm{D}$ residing constitutively in the nucleus of cells, a fact that indicates that sequences in the NTD of the hGR may play an important role in nuclear translocation, nuclear export and/or cytoplasmic retention of the receptor. In addition, these translational isoforms display significant differences in their ability to regulate gene expression, with the hGR $\alpha-C$ isoforms being the most active, and the hGR $\alpha$-D subtypes being the most "deficient" in their ability to transactivate glucocorticoid-responsive genes [7]. Recent evidence suggests that hGR $\alpha-C 3$ displays higher transcriptional activity than the other hGR $\alpha$ isoforms, owing to increased recruitment of coactivators at the promoter regions of target genes [8]. In addition to the hGR isoforms generated by alternative splicing or alternative initiation of translation, four novel receptor variants with multiple amino acid replacements/truncation have been described [hGR NS-1, hGR DL-1, hGR-S1 and hGR-S1 (-349A)] [9,10]. Their functional role remains to be elucidated.

The hGR regulates gene expression by either transcriptional activation (transactivation) or transcriptional repression (transrepression). Prior to binding to glucocorticoids, the hGR resides mostly in the cytoplasm of cells as part of a large multiprotein complex $[2,11]$. Upon ligand-induced activation, the receptor undergoes conformational changes that result in dissociation from this multiprotein complex and translocation into the nucleus, where it binds to glucocorticoid-response elements
(GREs) in the promoter region of target genes [2,11,12]. The latter contain hexamer domains in an inverted palindrome arrangement separated by 3 base pairs in the regulatory regions of target genes and regulate their expression positively or negatively through interaction with coactivators [12] or corepressors [2,11], respectively. Glucocorticoids may mediate anti-inflammatory effects via direct binding of hGR to evolutionarily conserved negative GREs (nGREs), which contain an inverted tetrameric palindrome separated by $0-2$ base pairs that is distinct from the classic GREs [13]. The ligand-activated hGR can also modulate gene expression independently of DNA-binding, by interacting with other transcription factors, such as nuclear factor- $\mathrm{kB}(\mathrm{NF}-\mathrm{k} \mathrm{B})$, activator protein-1 (AP-1), p53 and signal transducers and activators of transcription (STATs). The interaction of hGR with the pro-inflammatory transcription factors NF-kB and AP-1 inhibits their activity and accounts for the major anti-inflammatory and immunosuppressive effects of glucocorticoids [3]. Although the transcriptional activity of hGR is primarily governed by ligand binding, post-translational modifications also play important roles. These covalent changes include methylation, acetylation, nitrosylation, sumoylation, ubiquitination and phosphorylation, and may affect receptor stability, subcellular localization, as well as the interaction of hGR with other proteins [11].

In addition to the above-described genomic actions, glucocorticoids can induce some effects via the GR within seconds or minutes. The non-genomic rapid glucocorticoid actions appear to be mediated by membrane bound GRs, which trigger the activation of kinase signaling pathways, thus influencing many CNS and other tissue functions [14]. On the other hand, the MR functions as the 2nd glucocorticoid receptor in some tissues (e.g. limbic structure of the brain and adipose tissue), which do not express the glucocorticoid-inactivating 11ß-hydroxysteroid dehydrogenase 2, and cooperates with the classic GR to regulate expression of common and/or distinct target genes [15].

The cellular response to glucocorticoids displays profound variability both in magnitude and in specificity of action [2,11]. Multiple mechanisms exist to generate diversity, as well as specificity in the response to glucocorticoids, such as pre-receptor ligand metabolism, receptor isoform expression, and receptor-, tissue-, and cell type-specific factors. Furthermore, recent findings from in vitro and in vivo studies have demonstrated the important new role of old molecules, such as the serumand glucocorticoid-inducible kinase 1 (SGK1) [16,17] and FK506 -binding protein 51 (FKBP5) $[18,19]$, in tissue sensitivity to glucocorticoids and associated pathologic conditions. In addition to protein-protein interactions, tissue responsiveness to glucocorticoids has become more complicated since the identification and functional characterization of $h G R$ polymorphisms [20-24]. Interestingly, 
MR polymorphisms may also play some roles in tissue glucocorticoid sensitivity [25]. Any of the above-described molecular mechanisms may lead to alterations in tissue sensitivity to glucocorticoids, which may take the form of glucocorticoid resistance or glucocorticoid hypersensitivity and may be associated with significant morbidity (Table 1) [26]. This review summarizes the recent advances in the molecular mechanisms underlying tissue sensitivity to glucocorticoids, with particular emphasis on novel mutations and new information on the circadian rhythm of tissue sensitivity to glucocorticoids, and ligand-induced repression of the glucocorticoid receptor.

\section{Pathologic natural $h G R$ gene mutations causing primary generalized glucocorticoid resistance or Chrousos syndrome}

Natural $h G R$ gene mutations impair the molecular mechanisms of hGR action and alter tissue sensitivity to glucocorticoids [27-49]. The majority of the natural $h G R$ mutations described to date are associated with Chrousos syndrome, a rare, familial or sporadic genetic condition characterized by generalized, partial, target-tissue insensitivity to glucocorticoids (Figure 1). Affected subjects have compensatory activation of the HPA axis and elevations in circulating cortisol and adrenocorticotropic hormone $(\mathrm{ACTH})$ concentrations throughout the 24hour period without, however, any clinical manifestations of hypercortisolism. The excess ACTH secretion results in adrenal hyperplasia, and increased production of adrenal steroids with mineralocorticoid activity [cortisol, deoxycorticosterone (DOC) and corticosterone] and/ or androgenic activity [androstenedione, dehydroepiandrosterone (DHEA) and DHEA-sulfate (DHEAS)], and the corresponding clinical phenotype (Tables 2 and 3) [27-45,47-49].

We have recently described a new case of Chrousos syndrome caused by a novel, heterozygous, point mutation (V423A) in the DBD of the hGR $\alpha$, and investigated the molecular mechanisms through which the hGR $\alpha$ V423A affects glucocorticoid signal transduction. Compared with the wild-type receptor, the mutant receptor hGR $\alpha$ V423A demonstrated a significant reduction
(72\%) in its ability to transactivate glucocorticoidresponsive genes, impaired ability to bind to GREs and a marked delay (2.6-fold) in the time required to translocate into the nucleus. However, the hGR $\alpha$ V423A did not exert a dominant negative effect upon the wild-type hGR $\alpha$, had a similar affinity for the ligand, and displayed a normal interaction with the glucocorticoid receptor-interacting protein-1 (GRIP1) coactivator (Figure 2) [47].

Structural biology studies using computer-based creation of the 3-dimentional structure of the hGR DBD harboring the V423A mutation showed that the V423A substitution alters the hydrophobic nature of the first zinc finger of the hGR $\alpha$ DBD, and permits water to diffuse into the nearby zinc-binding site. The hydrophobic valine $(\mathrm{V})$ at position 423 in the hGR $\alpha$ DBD shields the four zinc-binding cysteines (C421, C424, C438, and C441) from water, thereby creating a hydrophobic environment. Replacement of valine (V) by alanine (A) at this position destroys the hydrophobic environment and permits water to diffuse into the ion-binding region of the protein, where it is captured by hydrogen bonds to C424 and C441, and reduces their affinity for binding to GREs [47]. These findings expand our knowledge on the previously described molecular mechanisms of action of natural $h G R$ mutants, and may explain the differences observed in the clinical phenotype of subjects with Chrousos syndrome [27-45,47-49].

\section{CLOCK-mediated acetylation of hGR: Implications for circadian rhythm-mediated regulation of glucocorticoid action in target tissues}

In humans, circulating cortisol concentrations are tightly regulated by the central components of the HPA axis and fluctuate naturally in an ultradian and circadian fashion, reaching their zenith in the early morning and their nadir in the late evening [1]. Stavrera et al. showed that ultradian glucocorticoid pulses resulted in dynamic association and dissociation of GR with the promoters of target genes leading to cyclic GR-mediated transcriptional regulation [50]. Interestingly, this coupling was not observed upon exposure of cells to synthetic glucocorticoids, since these were shown to prevent the dissociation of GR from

Table 1 Expected clinical manifestations in tissue-specific glucocorticoid resistance or hypersensitivity

\begin{tabular}{lll}
\hline Target tissue & Glucocorticoid hypersensitivity= Glucocorticoid excess & Glucocorticoid resistance = Glucocorticoid deficiency \\
\hline Central nervous system & Insomnia, anxiety, depression, defective cognition & Fatigue, somnolence, malaise, defective cognition \\
Liver & + Gluconeogenesis, + lipogenesis & Hypoglycemia, resistance to diabetes mellitus \\
Fat & Accumulation of visceral fat (metabolic syndrome) & Loss of weight, resistance to weight gain \\
Blood vessels & Hypertension & Hypotension \\
Bone & Stunted growth, osteoporosis & + Inflammation, + autoimmunity, + allergy
\end{tabular}




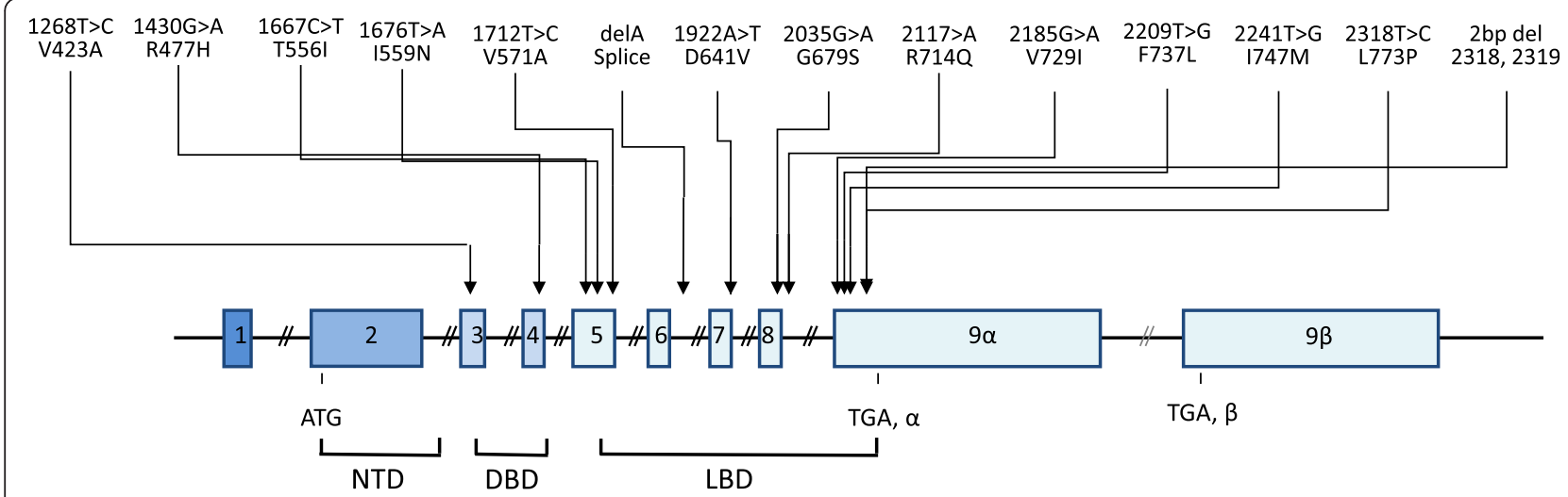

Figure 1 Schematic representation of the known mutations of the $h G R$ gene causing Chrousos syndrome. DBD: DNA-binding domain; LBD: ligand-binding domain; NTD: amino terminal domain.

the target promoter [50]. In addition to the above findings at the level of target tissues, recent studies have investigated the molecular mechanisms underlying glucocorticoid oscillations [51-53]. Walker et al. employed a mathematical model to study how the HPA axis supports ultradian glucocorticoid fluctuations [51]. They demonstrated that the pituitary-adrenal axis can produce ACTH and glucocorticoid ultradian oscillations in the presence of constant levels of CRH [51]. Their results were further confirmed by in vivo studies [53]. Indeed, a constant CRH input in the pituitary-adrenal axis resulted in physiological ultradian fluctuations of $\mathrm{ACTH}$ and glucocorticoids, whereas higher levels of $\mathrm{CRH}$ led to the disruption of the oscillating patterns [53]. On the other hand, the circadian secretion of cortisol is generated by an evolutionary conserved molecular 'clock', the circadian clock system, which consists of central and peripheral components $[54,55]$. The central clock system, located in the suprachiasmatic nucleus ( $\mathrm{SCN}$ ) of the hypothalamus, acts as the 'master' oscillator and generator of the body's circadian rhythm under the strong influence of the light/dark input from the eyes $[50,54,55]$. Interestingly, the neurons of SCN do not express GR; therefore glucocorticoid feedback does not directly affect the activity of the master SCN clock.

Table 2 Clinical manifestations and diagnostic evaluation of primary generalized glucocorticoid resistance or Chrousos Syndrome

\begin{tabular}{|c|c|}
\hline Clinical presentation & Diagnostic evaluation \\
\hline Apparently normal glucocorticoid function & Absence of clinical features of Cushing syndrome \\
\hline Asymptomatic & Normal or elevated plasma ACTH concentrations \\
\hline Hypoglycemia & Elevated plasma cortisol concentrations \\
\hline Chronic fatigue (glucocorticoid deficiency?) & Increased 24-hour urinary free cortisol excretion \\
\hline Mineralocorticoid excess & Normal circadian and stress-induced pattern of cortisol and ACTH secretion \\
\hline Hypertension & Resistance of the HPA axis to dexamethasone suppression \\
\hline Hypokalemic alkalosis & $\begin{array}{l}\text { Thymidine incorporation assays: Increased resistance to dexamethasone- } \\
\text { induced suppression of phytohemaglutinin-stimulated thymidine } \\
\text { incorporation compared to control subjects }\end{array}$ \\
\hline Androgen excess & $\begin{array}{l}\text { Dexamethasone-bindings assays: Decreased affinity of the glucocorticoid } \\
\text { receptor for the ligand compared to control subjects }\end{array}$ \\
\hline $\begin{array}{l}\text { Children: Ambiguous genitalia at birth*, premature adrenarche, } \\
\text { precocious puberty }\end{array}$ & Molecular studies: Mutations/deletions of the glucocorticoid receptor \\
\hline \multicolumn{2}{|l|}{$\begin{array}{l}\text { Females: Acne, hirsutism, male-pattern hair loss, menstrual irregularities, } \\
\text { oligo-anovulation, infertility }\end{array}$} \\
\hline \multicolumn{2}{|l|}{ Males: Acne, hirsutism, oligospermia, adrenal rests in the testes, infertility } \\
\hline \multicolumn{2}{|l|}{ Increased HPA axis activity (CRH/ACTH hypersecretion) } \\
\hline \multicolumn{2}{|l|}{ Anxiety } \\
\hline Adrenal rests & \\
\hline
\end{tabular}

Modified from References [28] and [29].

*This is the only case of ambiguous genitalia documented in a child with 46,XX karyotype who also harbored a heterozygous mutation of the 21 -hydroxylase gene. 
Table 3 Mutations of the human glucocorticoid receptor gene causing primary generalized glucocorticoid resistance or hypersensitivity

\begin{tabular}{|c|c|c|c|c|c|}
\hline & & & Mutation position & & \\
\hline Author (Reference) & cDNA & Amino acid & Molecular mechanisms & Genotype & Phenotype \\
\hline Chrousos et al. [27] & $1922(A \rightarrow T)$ & $641(D \rightarrow V)$ & Transactivation $\downarrow$ & Homozygous & Hypertension \\
\hline \multirow[t]{3}{*}{ Hurley et al. [32] } & & & Affinity for ligand $\downarrow(\times 3)$ & & Hypokalemic alkalosis \\
\hline & & & Nuclear translocation: 22 min & & \\
\hline & & & Abnormal interaction with GRIP1 & & \\
\hline \multirow[t]{3}{*}{ Karl et al. [33] } & 4 bp deletion in & & hGRa number: $50 \%$ of control & Heterozygous & Hirsutism \\
\hline & exon-intron 6 & & Inactivation of the affected allele & & Male-pattern hair-loss \\
\hline & & & & & Menstrual irregularities \\
\hline \multirow[t]{4}{*}{ Malchoff et al. [34] } & $2185(G \rightarrow A)$ & $729(V \rightarrow I)$ & Transactivation $\downarrow$ & Homozygous & Precocious puberty \\
\hline & & & Affinity for ligand $\downarrow(\times 2)$ & & Hyperandrogenism \\
\hline & & & Nuclear translocation: 120 min & & \\
\hline & & & Abnormal interaction with GRIP1 & & \\
\hline Karl et al. [31] & $1676(T \rightarrow A)$ & $559(\mathrm{l} \rightarrow \mathrm{N})$ & Transactivation $\downarrow$ & Heterozygous & Hypertension \\
\hline \multirow[t]{4}{*}{ Kino et al. [35] } & & & Decrease in hGR binding sites & & Oligospermia \\
\hline & & & Transdominance $(+)$ & & Infertility \\
\hline & & & Nuclear translocation: 180 min & & \\
\hline & & & Abnormal interaction with GRIP1 & & \\
\hline Ruiz et al. [36] & $1430(\mathrm{G} \rightarrow \mathrm{A})$ & $477(\mathrm{R} \rightarrow \mathrm{H})$ & Transactivation $\downarrow$ & Heterozygous & Hirsutism \\
\hline \multirow[t]{2}{*}{ Charmandari et al. [41] } & & & No DNA binding & & Fatigue \\
\hline & & & Nuclear translocation: 20 min & & Hypertension \\
\hline Ruiz et al. [36] & $2035(G \rightarrow A)$ & $679(\mathrm{G} \rightarrow \mathrm{S})$ & Transactivation $\downarrow$ & Heterozygous & Hirsutism \\
\hline \multirow[t]{3}{*}{ Charmandari et al. [41] } & & & Affinity for ligand $\downarrow(\times 2)$ & & Fatigue \\
\hline & & & Nuclear translocation: 30 min & & Hypertension \\
\hline & & & Abnormal interaction with GRIP1 & & \\
\hline \multirow[t]{4}{*}{ Mendonca et al. [37] } & $1712(T \rightarrow C)$ & $571(\mathrm{~V} \rightarrow \mathrm{A})$ & Transactivation $\downarrow$ & Homozygous & Ambiguous genitalia \\
\hline & & & Affinity for ligand $\downarrow(\times 6)$ & & Hypertension \\
\hline & & & Nuclear translocation: 25 min & & Hypokalemia \\
\hline & & & Abnormal interaction with GRIP1 & & Hyperandrogenism \\
\hline \multirow[t]{5}{*}{ Vottero et al. [38] } & $2241(\mathrm{~T} \rightarrow \mathrm{G})$ & $747(\mathrm{I} \rightarrow \mathrm{M})$ & Transactivation $\downarrow$ & Heterozygous & Cystic acne \\
\hline & & & Transdominance $(+)$ & & Hirsutism \\
\hline & & & Affinity for ligand $\downarrow(\times 2)$ & & Oligo-amenorrhea \\
\hline & & & Nuclear translocation $\downarrow$ & & \\
\hline & & & Abnormal interaction with GRIP1 & & \\
\hline \multirow[t]{5}{*}{ Charmandari et al. [40] } & $2318(T \rightarrow C)$ & $773(\llcorner\rightarrow P)$ & Transactivation $\downarrow$ & Heterozygous & Fatigue \\
\hline & & & Transdominance $(+)$ & & Anxiety \\
\hline & & & Affinity for ligand $\downarrow(\times 2.6)$ & & Acne \\
\hline & & & Nuclear translocation: 30 min & & Hirsutism \\
\hline & & & Abnormal interaction with GRIP1 & & Hypertension \\
\hline \multirow[t]{4}{*}{ Charmandari et al. [42] } & $2209(T \rightarrow C)$ & $737(F \rightarrow L)$ & Transactivation $\downarrow$ & Heterozygous & Hypertension \\
\hline & & & Transdominance (time-dependent) (+) & & Hypokalemia \\
\hline & & & Affinity for ligand $\downarrow(\times 1.5)$ & & \\
\hline & & & Nuclear translocation: 180 min & & \\
\hline
\end{tabular}


Table 3 Mutations of the human glucocorticoid receptor gene causing primary generalized glucocorticoid resistance or hypersensitivity (Continued)

\begin{tabular}{|c|c|c|c|c|c|}
\hline \multirow[t]{3}{*}{ McMahon et al. [43] } & $2 \mathrm{bp}$ deletion & 773 & Transactivation $\downarrow$ & Homozygous & Hypoglycemia \\
\hline & at nt 2318-9 & & Affinity for ligand: absent & & Fatigability with feeding \\
\hline & & & No suppression of IL-6 & & Hypertension \\
\hline \multirow[t]{6}{*}{ Nader et al. [44] } & $2141(\mathrm{G} \rightarrow \mathrm{A})$ & $714(R \rightarrow Q)$ & Transactivation $\downarrow$ & Heterozygous & Hypoglycemia \\
\hline & & & Transdominance $(+)$ & & Hypokalemia \\
\hline & & & Affinity for ligand $\downarrow(\times 2)$ & & Hypertension \\
\hline & & & Nuclear translocation $\downarrow$ & & Mild clitoromegaly \\
\hline & & & Abnormal interaction with GRIP1 & & Advanced bone age \\
\hline & & & & & Precocious pubarche \\
\hline Zhu Hui-juan et al. [45] & $1667(G \rightarrow T)$ & $556(T \rightarrow I)$ & Not studied yet & Heterozygous & Adrenal incidentaloma \\
\hline \multirow[t]{5}{*}{ Charmandari et al. [46] } & $1201(\mathrm{G} \rightarrow \mathrm{C})$ & $401(\mathrm{D} \rightarrow \mathrm{H})$ & Transactivation $\uparrow$ & Heterozygous & Visceral obesity \\
\hline & & & Transdominance $(+)$ & & Hypercholesterolemia \\
\hline & & & Affinity for ligand: $N$ & & Hypertriglyceridemia \\
\hline & & & Nuclear translocation: N & & Hypertension \\
\hline & & & Interaction with GRIP1: N & & Diabetes type 2 \\
\hline \multirow[t]{5}{*}{ Roberts et al. [47] } & $1268(T \rightarrow C)$ & $423(V \rightarrow A)$ & Transactivation $\downarrow$ & Heterozygous & Fatigue \\
\hline & & & Affinity for ligand: $N$ & & Anxiety \\
\hline & & & No DNA binding & & Hypertension \\
\hline & & & Nuclear translocation: 35 min & & \\
\hline & & & Interaction with GRIP1: N & & \\
\hline \multirow[t]{5}{*}{ Nicolaides et al. [48] } & $1724(\mathrm{~T} \rightarrow \mathrm{G})$ & $575(\mathrm{~V} \rightarrow \mathrm{G})$ & Transactivation $\downarrow$ & Heterozygous & Melanoma \\
\hline & & & Transrepression $\uparrow$ & & Asymptomatic daughters \\
\hline & & & Affinity for ligand $\downarrow(\times 2)$ & & \\
\hline & & & Nuclear translocation $\downarrow$ & & \\
\hline & & & Abnormal interaction with GRIP1 & & \\
\hline
\end{tabular}

Modified from References [29] and [30].

Numbers in the parentheses following authors' names indicate the corresponding references.

The peripheral clock system, which is distributed in all organs and tissues, including the central nervous system outside the $\mathrm{SCN}$, acts generally as a 'slave' clock under the regulation of the central SCN clock, by as yet unknown mechanism(s) [54-56]. Both clocks communicate with each other and generate circadian rhythmicity by the coordinated activation/inactivation of self-oscillating transcription factors. Central among them are the circadian locomotor output cycle kaput (CLOCK) and its heterodimer partner brain-muscle-arnt-like protein 1 (BMAL1) [54-56].

We have recently demonstrated that CLOCK physically interacts with the LBD of the hGR and suppresses the hGR-induced transcriptional activity by acetylating multiple lysine residues $(480,492,494$, and 495$)$ in the hinge region of the receptor. This post-translational modification attenuates the binding of hGR to GREs and its ability to influence glucocorticoid-responsive gene expression. Furthermore, the expression of glucocorticoid- responsive genes fluctuated in a circadian fashion, mirroring in reverse phase the Clock/Bmal1 expression [57]. These findings indicate that CLOCK/BMAL1 is a reversephase negative regulator of glucocorticoid action in target tissues, antagonizing the biologic actions of diurnally fluctuating circulating glucocorticoids and providing a local target tissue counter-regulatory feedback loop to the central clock influence on the HPA axis [57]. As a result, tissue sensitivity to glucocorticoids is decreased in the morning (when circulating cortisol concentrations are elevated) and increased in the evening and early night (when cortisol concentrations reach their nadir) (Figure 3).

In addition to these in vitro findings, we examined the acetylation status of hGR and the expression of clockrelated and glucocorticoid-responsive genes in vivo and ex vivo, using peripheral blood mononuclear cells from healthy adult volunteers [58]. The levels of acetylated hGR were higher in the morning and lower in the evening, mirroring the fluctuations of circulating cortisol concentrations 


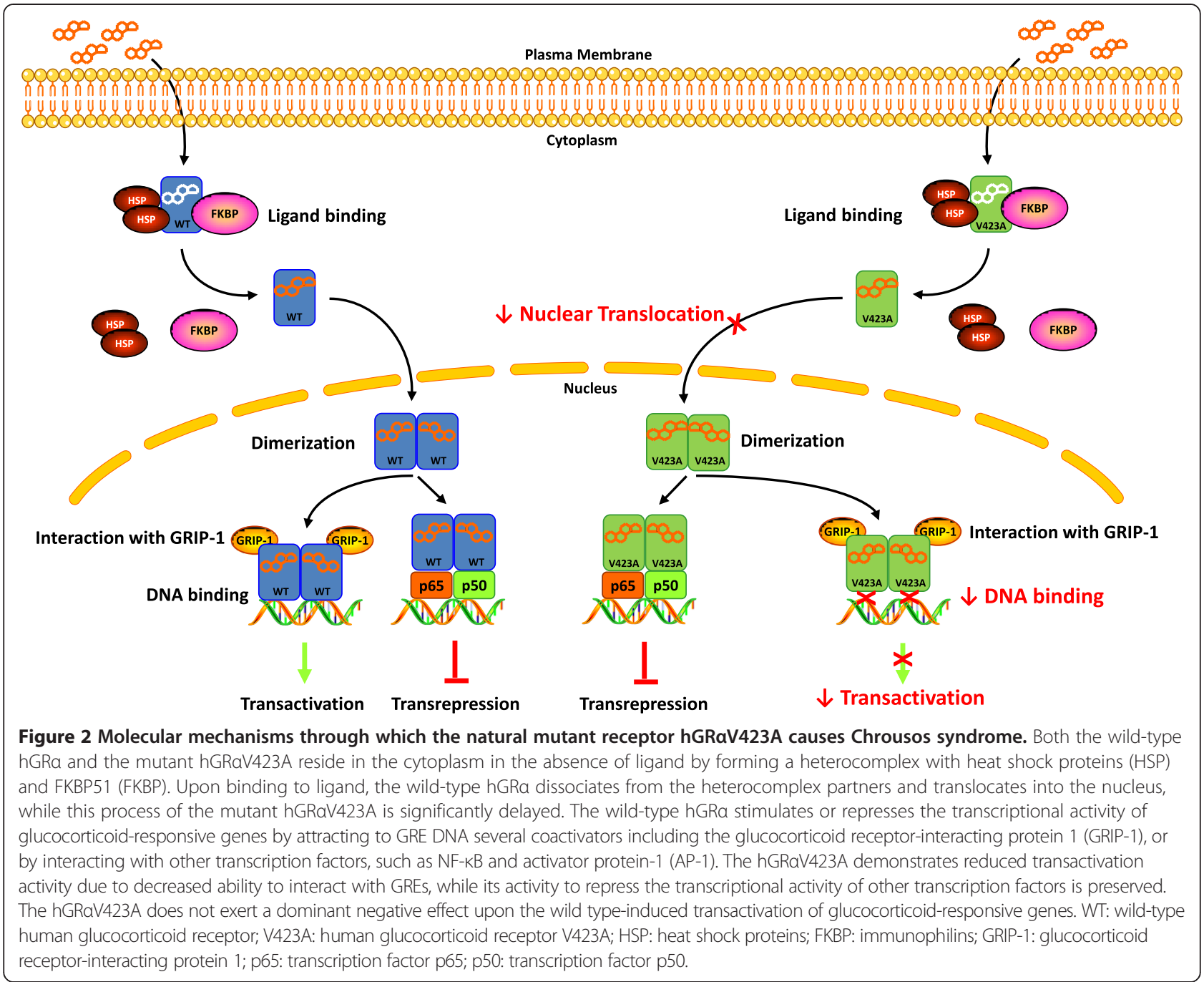

in reverse phase. All known glucocorticoid-responsive genes tested responded as expected to hydrocortisone, however, some of these genes did not show the expected diurnal mRNA fluctuations in vivo. Instead, their mRNA did not oscillate in the absence of endogenous glucocorticoid, indicating that circulating cortisol might prevent circadian GR acetylation-dependent effects in some glucocorticoid-responsive genes in vivo. These findings suggest that peripheral CLOCK-mediated circadian acetylation of the hGR functions as a target-tissue, gene-specific counter-regulatory mechanism to the actions of diurnally fluctuating cortisol, effectively decreasing tissue sensitivity to glucocorticoids in the morning and increasing it in the evening and early night [58]. Furthermore, in another recent study that determined the mRNA expression of $\sim 190$ hGR action-regulating and glucocorticoid-responsive genes in subcutaneous fat biopsies obtained from 25 obese subjects, circulating cortisol concentrations in the evening were more important in regulating the mRNA expression of glucocorticoid-responsive genes than those in the morning [59]. Therefore, it appears that the higher tissue sensitivity to glucocorticoids in the evening, owing to reduced hGR acetylation by CLOCK, underlies the stronger effect of elevated circulating cortisol concentrations on the expression of glucocorticoid-regulated genes in the evening and early night.

In line with our in vitro, in vivo and ex vivo results, Lamia et al. recently showed that CRY1 and CRY2 interacted with the GR in a ligand-dependent fashion, leading to direct inhibition of GR-mediated transactivation of glucocorticoid-responsive genes [60]. Interestingly, this CRY-GR interaction did not affect the transrepressing actions of GR on many inflammatory genes, indicating that cryptochromes, when interact with the GR, could influence the expression of a separate group of GR target genes. This dissociation of the transactivating and transrepressing activities of the GR might reduce the frequency of the undesirable metabolic effects during long-term 


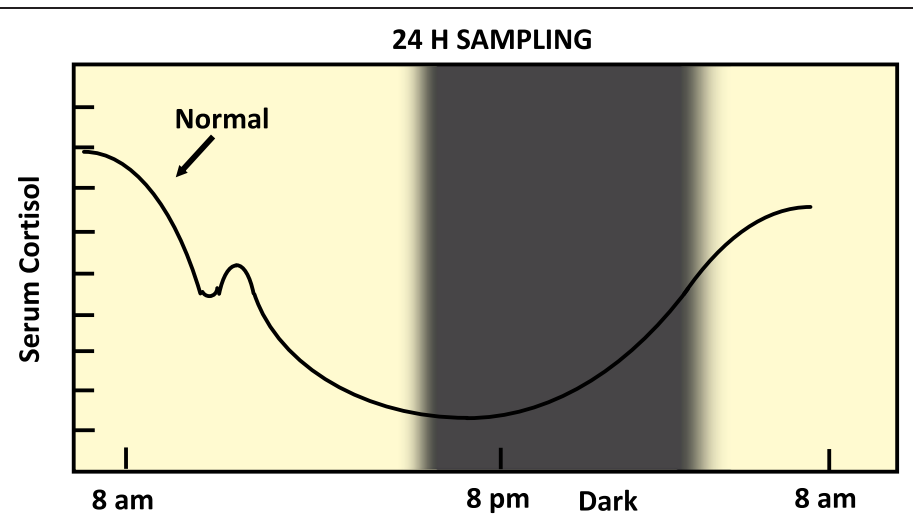

CIRCADIAN TISSUE GLUCOCORTICOID SENSITIVITY/GR ACETYLATION

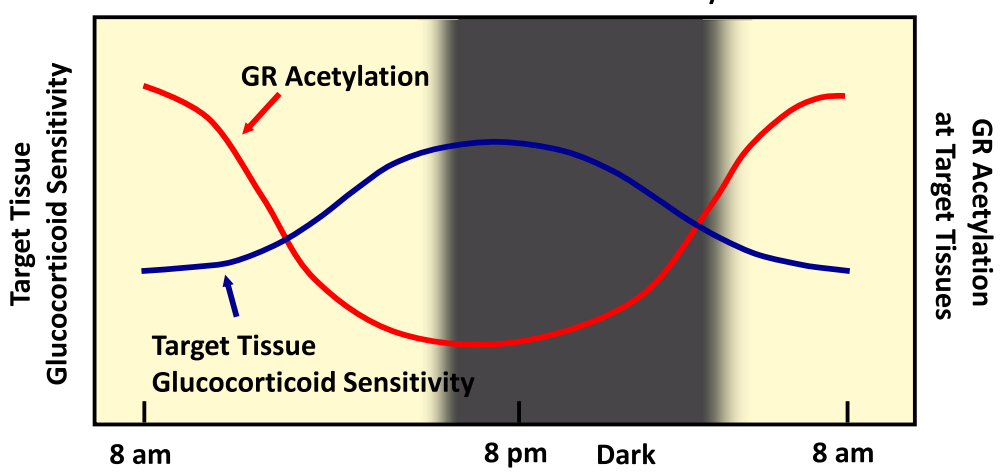

Figure 3 CLOCK-mediated gene-specific regulation of glucocorticoid action in peripheral target tissues. Circulating cortisol concentrations in humans fluctuate diurnally, as indicated in the top panel. The expression of glucocorticoid-target genes is also expected to fluctuate depending on the changes of circulating cortisol concentrations. However, this diurnal fluctuation of gene expression is suppressed through acetylation of GR by locally expressed CLOCKJBMAL1 heterodimers, possibly functioning as a local counter-regulatory feedback loop to the circulating glucocorticoids. Thus, high levels of acetylated GR in the morning are associated with low target-tissue sensitivity to glucocorticoids and vice versa in the evening and early night. Modified from Reference [56].

administration of synthetic glucocorticoids [60]. Moreover, a very recent study demonstrated that CLOCK/ BMAL1 reduced both maximal GR transactivation of target genes and the efficacy of the receptor to increase the transcription rate of glucocorticoid-responsive genes. On the other hand, the PER1/CRY1 complex reduced the maximal GR transactivation, but not the efficacy of the receptor, suggesting that both elements of the positive and negative arm of the clock system repress GR transcriptional activity [61].

The circadian clock system and the HPA axis regulate the activity of one another through multilevel interactions to ultimately coordinate homeostasis against the day/night change and various unforeseen random internal and external stressors. Uncoupling of or dysfunction in either system alters internal homeostasis and causes pathologic changes virtually in all organs and tissues, including those responsible for intermediary metabolism and immunity [62]. Disrupted coupling of cortisol secretion and target tissue sensitivity to glucocorticoids may account for i) the development of central obesity and the metabolic syndrome in chronically stressed individuals, whose HPA axis circadian rhythm is characterized by blunting of the evening decreases of circulating glucocorticoids, as a result of enhanced input of higher centers upon the hypothalamic paraventricular nucleus secretion of CRH and AVP; and ii) the increased cardiometabolic risk and increased mortality of rotating shift workers or subjects exposed to frequent jet lag because of traveling across time zones [56,63]. In addition, given that tissue sensitivity to glucocorticoids is increased in the evening, clinicians should avoid the administration of high doses of glucocorticoids for the treatment of adrenal insufficiency or congenital adrenal hyperplasia at night, because they increase the possibility of glucocorticoid-related side effects.

At pharmacological concentrations, the transactivational activity of glucocorticoids is correlated with the side effects of these steroids, while their transrepressive activity is associated mostly with their beneficial anti- 
inflammatory activity. Since CLOCK may differentially regulate these two major class actions of glucocorticoids, administration of these steroids at a specific period of the circadian cycle might increase their pharmacological efficacy, while at the same time reduce their unwanted side effects [62].

\section{Ligand-induced down-regulation (repression) of $h G R$ gene expression}

Glucocorticoids are among the most potent and effective agents for treating inflammatory diseases and hematologic malignancies. However, a number of patients are often resistant to treatment with glucocorticoids [1-4]. Therefore, it is important to determine the molecular mechanisms underlying this phenomenon in order to adequately treat patients with these disorders.

Recent studies investigated the molecular mechanisms responsible for repression of $h G R$ gene transcription by glucocorticoids. They demonstrated that glucocorticoid treatment resulted in a rapid decrease in nascent hGR RNA, with maximal repression being sustained for 6 to $8 \mathrm{~h}$. They also identified a functional nGRE in exon 6 of the $h G R$ gene, which played an important role in the repression of the $h G R$ gene. Upon ligand-induced activation, the hGR bound to the nGRE on exon 6 and recruited NCoR1 (nuclear receptor corepressor) and HDAC3 (histone deacetylase 3) to the promoter-proximal region, thereby forming a repression complex and inhibiting hGR transcription [64]. These findings indicate that the hGR concentration can be down-regulated coordinately with excess ligand, regardless of the combinatorial associations of tissue-specific transcription factors. Therefore, although glucocorticoid-induced down-regulation of hGR represents a mechanism for maintaining glucocorticoid homeostasis in normal cells, it appears to have the potential to limit the therapeutic response to glucocorticoids in inflammatory and malignant conditions. As a result, longterm glucocorticoid treatment in patients with the above disorders may lead to constitutive hGR transrepression and glucocorticoid resistance.

In addition to glucocorticoid-induced down-regulation of hGR, the expression of the receptor has been shown to be influenced by epigenetic modifications which occurred in the context of gene-environment interactions. In their pioneering study, Weaver and collaborators demonstrated that maternal behavior had a pivotal role in stress responses of offspring. Indeed, rats exposed to low levels of pup licking and grooming (LG) and archedback nursing $(\mathrm{ABN})$ by their mothers, had increased methylation of the $1_{7}$ promoter of the GR gene, leading to decreased levels of GR in the hippocampus and altered response of the HPA axis to stressors [65]. This epigenetic alteration of GR expression could also be involved in drug-induced glucocorticoid resistance. Moreover, GR protein levels were found to be reduced by micro-RNAs (miRs), such as miR-18a [66], -18 and -124a [67] in neuronal tissues. Uchida et al. used Fischer 344 (F344) rats, a well-known stress-hyperresponsive model, and showed that this strain, upon a 14-day repeat restrain stress, had increased levels of miR-18a and decreased GR protein expression in the PVN, compared with control SpragueDawley (SD) rats [66]. Further studies have supported the implication of microRNAs, specifically miR-18 and $-124 a$, in brain responsiveness to glucocorticoids. Both miR-18 and -124a down-regulated the GR, establishing their critical role in the regulation of glucocorticoid responsiveness of the brain [67]. On the other hand, the specific downregulation of the GR in newborn hippocampal cells, using viral-mediated RNA-interference in vivo, increased their neuronal differentiation and migration, as well as their basal excitability. These morphological and functional alterations of hippocampal cells resulted in impairments in memory consolidation [68]. Therefore, blockade of selective GR-dependent processes in brain would be therapeutically beneficial. Zalachoras et al. demonstrated that the non-steroidal GR ligand $1 \mathrm{H}$-pyrazolo[3,4- $g$ ] hexahydroisoquinoline or C108297 selectively modulated GR activity in the brain by suppressing $\mathrm{CRH}$ gene expression while enhancing GR-dependent memory consolidation by acting as a unique GR modulator [69]. In contradistinction, C108297 antagonized GR-mediated reduction in neurogenesis in the hippocampus following long-term administration of glucocorticoids [69]. Thus, C108297 has a potential to selectively abrogate pathogenic processes associated with GR in the brain, while retaining some beneficial actions of this receptor.

\section{Conclusions}

The glucocorticoid receptor is a ubiquitously expressed intracellular, ligand-dependent transcription factor, which mediates the action of glucocorticoids and influences physiologic functions essential for life. The traditional view that glucocorticoids exert their diverse effects through one receptor protein has changed dramatically over the last two decades with the discovery of multiple hGR isoforms arising from the single $h G R$ gene. hGR subtypes with unique expression and gene regulatory profiles are generated by alternative splicing of the nascent transcript, alternative translation initiation of the mature mRNA, and post-translational modifications of the receptor protein. The capacity of a cell to generate dozens of hGR isoforms that control specific sets of genes and/or differentially regulate common sets provides enormous potential for signaling diversity. Further contributing to the tissue- and cell-specific effects of glucocorticoids is the potential for these isoforms to heterodimerize with each other and cross-talk with other signaling molecules. The combinatorial nature of glucocorticoid signaling pathways 
indicates that alterations in hGR action may have important implications for many critical biological processes and may account for the alterations in tissue sensitivity to glucocorticoids, as well as the variations in response to glucocorticoid treatment documented in clinical practice. A greater understanding of the role that hGR heterogeneity plays in the cellular response to glucocorticoids should aid in the development of new glucocorticoid compounds with selective activities that may offer the prospect of an improved outcome with lesser side effects.

\section{Competing interests}

The authors declare that they have no competing interests.

\section{Authors' contributions}

NCN carried out the literature search, participated in the preparation of Tables and Figures, and revised the manuscript. EC carried out the literature search, the analysis of the data and wrote the manuscript. GPC and TK reviewed the manuscript critically and offered their comments. All authors read and approved the final manuscript.

\section{Acknowledgements}

This work was supported by i) the European Union (European Social Fund ESF) and Greek national funds through the Operational Program "Education and Lifelong Learning" of the National Strategic Reference Framework (NSRF) - Research Funding Program: THALIS -University of Athens (UOA), Athens, Greece; and ii) the intramural program of the Eunice Kennedy Shriver National Institute of Child Health and Human Development, National Institutes of Health, Bethesda, Maryland, 20892, USA.

\section{Author details}

'Division of Endocrinology, Metabolism and Diabetes, First Department of Pediatrics, University of Athens Medical School, 'Aghia Sophia' Children's Hospital, Athens 11527, Greece. 'Division of Endocrinology and Metabolism, Clinical Research Center, Biomedical Research Foundation of the Academy of Athens, Athens 11527, Greece. ${ }^{3}$ Saudi Diabetes Study Research Group, King Fahd Medical Research Center, King Abdulaziz University, Jeddah, Saudi Arabia. ${ }^{4}$ Unit on Molecular Hormone Action, Program in Reproductive and Adult Endocrinology, Eunice Kennedy Shriver National Institute of Child Health and Human Development, National Institutes of Health, Bethesda, Maryland 2089, USA.

Received: 13 January 2014 Accepted: 31 July 2014

Published: 25 August 2014

\section{References}

1. Kino T, Chrousos GP: Glucocorticoid effects on gene expression. In Handbook of Stress and the Brain. Edited by Steckler T, Kalin NH, Reul JMHM. Amsterdam: Elsevier; 2005:295-311.

2. Nicolaides NC, Galata Z, Kino T, Chrousos GP, Charmandari E: The human glucocorticoid receptor: molecular basis of biologic function. Steroids 2010, 75(1):1-12.

3. Rhen T, Cidlowski JA: Anti-inflammatory action of glucocorticoids-new mechanisms for old drugs. N Engl J Med 2005, 353(16):1711-1723.

4. Schmidt S, Rainer J, Ploner C, Presul E, Riml S, Kofler R: Glucocorticoidinduced apoptosis and glucocorticoid resistance: molecular mechanisms and clinical relevance. Cell Death Differ 2004, 11:S45-S55.

5. Zhou J, Cidlowski JA: The human glucocorticoid receptor: one gene, multiple proteins and diverse responses. Steroids 2005, 70:407-417.

6. Cole TJ, Blendy JA, Monaghan AP, Krieglstein K, Schmid W, Aguzzi A Fantuzzi G, Hummler E, Unsicker K, Schütz G: Targeted disruption of the glucocorticoid receptor gene blocks adrenergic chromaffin cell development and severely retards lung maturation. Genes Dev 1995, 9:1608-1621.

7. Oakley RH, Cidlowski JA: Cellular processing of the glucocorticoid receptor gene and protein: new mechanisms for generating tissuespecific actions of glucocorticoids. J Biol Chem 2011, 286:3177-3184.
8. Bender IK, Cao Y, Lu NZ: Determinants of the heightened activity of glucocorticoid receptor translational isoforms. Mol Endocrinol 2013, 27:1577-1587

9. Tung K, Baker AC, Amini A, Green TL, Chew WW, Lim D, Nguyen ST, Yee KS, Cho K, Greenhalgh DG: Novel hyperactive glucocorticoid receptor isoform identified within a human population. Shock 2011, 36:339-344.

10. Baker AC, Green TL, Chew WW, Tung K, Amini A, Lim D, Cho K, Greenhalgh DG: Enhanced steroid response of a human glucocorticoid receptor splice variant. Shock 2012, 38:11-17.

11. Chrousos GP, Kino T: Intracellular glucocorticoid signaling: a formerly simple system turns stochastic. Sci STKE 2005, 2005:pe48.

12. Lachize S, Apostolakis EM, van der Laan S, Tijssen AMl, Xu J, de Kloet ER, Meijer OC: Steroid receptor coactivator-1 is necessary for regulation of corticotropin-releasing hormone by chronic stress and glucocorticoids. Proc Natl Acad Sci U S A 2009, 106:8038-8042.

13. Surjit M, Ganti KP, Mukherji A, Ye T, Hua G, Metzger D, Li M, Chambon P: Widespread negative response elements mediate direct repression by agonist-liganded glucocorticoid receptor. Cell 2011, 145:224-241.

14. Groeneweg FL, Karst H, de Kloet ER, Joels M: Rapid non-genomic effects of corticosteroids and their role in the central stress response. J Endocrinol 2011, 209:153-167.

15. Datson NA, van der Perk J, de Kloet ER, Vreugdenhil E: Identification of corticosteroid-responsive genes in rat hippocampus using serial analysis of gene expression. Eur J Neurosci 2001, 14:675-689.

16. Anacker C, Cattaneo A, Musaelyan K, Zunszain PA, Horowitz M, Molteni R, Luoni A, Calabrese F, Tansey K, Gennarelli M, Thuret S, Price J, Uher R, Riva MA, Pariante CM: Role for the kinase SGK1 in stress, depression, and glucocorticoid effects on hippocampal neurogenesis. Proc Natl Acad Sci U S A 2013, 110:8708-8713.

17. Schwab M, Lupescu A, Mota M, Mota E, Frey A, Simon P, Mertens PR, Floege J, Luft F, Asante-Poku S, Schaeffeler E, Lang F: Association of SGK1 gene polymorphisms with type 2 diabetes. Cell Physiol Biochem 2008, 21:151-160.

18. Menke A, Klengel T, Rubel J, Brückl T, Pfister H, Lucae S, Uhr M, Holsboer F, Binder EB: Genetic variation in FKBP5 associated with the extent of stress hormone dysregulation in major depression. Genes Brain Behav 2013, 12:289-296

19. Hartmann J, Wagner KV, Liebl C, Scharf SH, Wang XD, Wolf M, Hausch F, Rein T, Schmidt U, Touma C, Cheung-Flynn J, Cox MB, Smith DF, Holsboer F, Müller MB, Schmidt MV: The involvement of FK506-binding protein 51 (FKBP5) in the behavioral and neuroendocrine effects of chronic social defeat stress. Neuropharmacology 2012, 62:332-339.

20. Huizenga NA, Koper JW, De Lange P, Pols HA, Stolk RP, Burger H, Grobbee $\mathrm{DE}$, Brinkmann AO, De Jong FH, Lamberts SW: A polymorphism in the glucocorticoid receptor gene may be associated with and increased sensitivity to glucocorticoids in vivo. J Clin Endocrinol Metab 1998, 83:144-151.

21. Dobson MG, Redfern CP, Unwin N, Weaver JU: The N363S polymorphism of the glucocorticoid receptor: potential contribution to central obesity in men and lack of association with other risk factors for coronary heart disease and diabetes mellitus. J Clin Endocrinol Metab 2001, 86:2270-2274.

22. Russcher H, van Rossum EF, de Jong FH, Brinkmann AO, Lamberts SW, Koper JW: Increased expression of the glucocorticoid receptor-A translational isoform as a result of the ER22/23EK polymorphism. Mol Endocrinol 2005, 19:1687-1696.

23. van Rossum EF, Voorhoeve PG, te Velde SJ, Koper JW, de Waal HA D-V, Kemper HC, Lamberts SW: The ER22/23EK polymorphism in the glucocorticoid receptor gene is associated with a beneficial body composition and muscle strength in young adults. J Clin Endocrinol Metab 2004, 89:4004-4009.

24. van Rossum EF, Koper JW, Huizenga NA, Uitterlinden AG, Janssen JA, Brinkmann AO, Grobbee DE, de Jong FH, van Duyn CM, Pols HA, Lamberts SW: A polymorphism in the glucocorticoid receptor gene, which decreases sensitivity to glucocorticoids in vivo, is associated with low insulin and cholesterol levels. Diabetes 2002, 51:3128-3134.

25. van Leeuwen N, Bellingrath S, de Kloet ER, Zitman FG, DeRijk RH, Kudielka BM, Wüst S: Human mineralocorticoid receptor (MR) gene haplotypes modulate MR expression and transactivation: implication for the stress response. Psychoneuroendocrinology 2011, 36:699-709.

26. Chrousos GP, Kino T: Glucocorticoid Signaling in the Cell: Expanding Clinical Implications to Complex Human Behavioral and Somatic 
Disorders. In: Glucocorticoids and Mood: Clinical Manifestations, Risk Factors, and Molecular Mechanisms. Proc NY Acad Sci 2009, 1179:153-166.

27. Chrousos GP, Vingerhoeds A, Brandon D, Eil C, Pugeat M, DeVroede M, Loriaux $\mathrm{DL}$, Lipsett MB: Primary cortisol resistance in man: a glucocorticoid receptormediated disease. J Clin Invest 1982, 69:1261-1269.

28. Charmandari E, Kino T, Ichijo T, Chrousos GP: Generalized glucocorticoid resistance: clinical aspects, molecular mechanisms, and implications of a rare genetic disorder. J Clin Endocrinol Metab 2008, 93:1563-1572.

29. Charmandari E, Kino T: Chrousos syndrome: a seminal report, a phylogenetic enigma and the clinical implications of glucocorticoid signalling changes. Eur J Clin Invest 2010, 40:932-942.

30. Charmandari E: Primary generalized glucocorticoid resistance and hypersensitivity. Horm Res Paediatr 2011, 76:145-155.

31. Karl M, Lamberts SW, Koper JW, Katz DA, Huizenga NE, Kino T, Haddad BR, Hughes MR, Chrousos GP: Cushing's disease preceded by generalized glucocorticoid resistance: clinical consequences of a novel, dominantnegative glucocorticoid receptor mutation. Proc Assoc Am Physicians 1996, 108:296-307.

32. Hurley DM, Accili D, Stratakis CA, Karl M, Vamvakopoulos N, Rorer E, Constantine K, Taylor SI, Chrousos GP: Point mutation causing a single amino acid substitution in the hormone binding domain of the glucocorticoid receptor in familial glucocorticoid resistance. J Clin Invest 1991, 87:680-686.

33. Karl M, Lamberts SW, Detera-Wadleigh SD, Encio IJ, Stratakis CA, Hurley DM, Accili D, Chrousos GP: Familial glucocorticoid resistance caused by a splice site deletion in the human glucocorticoid receptor gene. J Clin Endocrinol Metab 1993, 76:683-689.

34. Malchoff DM, Brufsky A, Reardon G, McDermott P, Javier EC, Bergh CH, Rowe $D$, Malchoff CD: A mutation of the glucocorticoid receptor in primary cortisol resistance. J Clin Invest 1993, 91:1918-1925.

35. Kino T, Stauber RH, Resau JH, Pavlakis GN, Chrousos GP: Pathologic human GR mutant has a transdominant negative effect on the wild-type GR by inhibiting its translocation into the nucleus: importance of the ligandbinding domain for intracellular GR trafficking. J Clin Endocrinol Metab 2001, 86:5600-5608.

36. Ruiz M, Lind U, Gafvels M, Eggertsen G, Carlstedt-Duke J, Nilsson L, Holtmann M, Stierna P, Wikstrom AC, Werner S: Characterization of two novel mutations in the glucocorticoid receptor gene in patients with primary cortisol resistance. Clin Endocrinol (Oxf) 2001, 55:363-371.

37. Mendonca BB, Leite MV, de Castro M, Kino T, Elias LL, Bachega TA, Arnhold IJ, Chrousos GP, Latronico AC: Female pseudohermaphroditism caused by a novel homozygous missense mutation of the GR gene. J Clin Endocrinol Metab 2002, 87:1805-1809.

38. Vottero A, Kino T, Combe H, Lecomte P, Chrousos GP: A novel, C-terminal dominant negative mutation of the GR causes familial glucocorticoid resistance through abnormal interactions with p160 steroid receptor coactivators. J Clin Endocrinol Metab 2002, 87:2658-2667.

39. Charmandari E, Kino T, Vottero A, Souvatzoglou E, Bhattacharyya N, Chrousos GP: Natural glucocorticoid receptor mutants causing generalized glucocorticoid resistance: Molecular genotype, genetic transmission and clinical phenotype. J Clin Endocrinol Metab 2004, 89:1939-1949.

40. Charmandari E, Raji A, Kino T, Ichijo T, Tiulpakov A, Zachman K, Chrousos GP: A novel point mutation in the ligand-binding domain (LBD) of the human glucocorticoid receptor ( $h G R$ ) causing generalized glucocorticoid resistance: the importance of the $C$ terminus of hGR LBD in conferring transactivational activity. J Clin Endocrinol Metab 2005, 90:3696-3705.

41. Charmandari E, Kino T, Ichijo T, Zachman K, Alatsatianos A, Chrousos GP. Functional characterization of the natural human glucocorticoid receptor (hGR) mutants hGRaR477H and hGRßG679S associated with generalized glucocorticoid resistance. J Clin Endocrinol Metab 2006, 91:1535-1543.

42. Charmandari E, Kino T, Ichijo T, Jubiz W, Mejia L, Zachman K, Chrousos GP: A novel point mutation in helix 11 of the ligand-binding domain of the human glucocorticoid receptor gene causing generalized glucocorticoid resistance. J Clin Endocrinol Metab 2007, 92:3986-3990.

43. McMahon SK, Pretorius CJ, Ungerer JP, Salmon NJ, Conwell LS, Pearen MA, Batch JA: Neonatal complete generalized glucocorticoid resistance and growth hormone deficiency caused by a novel homozygous mutation in Helix 12 of the ligand binding domain of the glucocorticoid receptor gene (NR3C1). J Clin Endocrinol Metab 2010, 95:297-302.
44. Nader N, Bachrach BE, Hurt DE, Gajula S, Pittman A, Lescher R, Kino T: A novel point mutation in the helix 10 of the human glucocorticoid receptor causes Generalized Glucocorticoid Resistance by disrupting the structure of the ligand-binding domain. J Clin Endocrinol Metab 2010, 95:2281-2285

45. Zhu HJ, Dai YF, Wang O, Li M, Lu L, Zhao WG, Xing XP, Pan H, Li NS, Gong FY: Generalized glucocorticoid resistance accompanied with an adrenocortical adenoma and caused by a novel point mutation of human glucocorticoid receptor gene. Chin Med J (Engl) 2011, 124:551-555.

46. Charmandari E, Ichijo T, Jubiz W, Baid S, Zachman K, Chrousos GP, Kino T: A novel point mutation in the amino terminal domain of the human glucocorticoid receptor (hGR) gene enhancing hGR-mediated gene expression. J Clin Endocrinol Metab 2008, 93:4963-4968.

47. Roberts ML, Kino T, Nicolaides NC, Hurt DE, Katsantoni E, Sertedaki A, Komianou F, Kassiou K, Chrousos GP, Charmandari E: A novel point mutation in the DNA-binding domain (DBD) of the human glucocorticoid receptor causes primary generalized glucocorticoid resistance by disrupting the hydrophobic structure of its DBD. J Clin Endocrinol Metab 2013, 98:E790-E795.

48. Nicolaides NC, Roberts ML, Kino T, Braatvedt G, Hurt DE, Katsantoni E, Sertedaki A, Chrousos GP, Charmandari E: A novel point mutation of the human glucocorticoid receptor gene causes primary generalized glucocorticoid resistance through impaired interaction with the LXXLL motif of the p160 coactivators: dissociation of the transactivating and transreppressive activities. J Clin Endocrinol Metab 2014, 99:E902-E907.

49. Chrousos G: Q\&A: primary generalized glucocorticoid resistance. BMC Med 2011, 9:27.

50. Stavreva DA, Wiench M, John S, Conway-Campbell BL, McKenna MA, Pooley JR, Johnson TA, Voss TC, Lightman SL, Hager GL: Ultradian hormone stimulation induces glucocorticoid receptor-mediated pulses of gene transcription. Nat Cell Biol 2009, 11:1093-1102.

51. Walker JJ, Terry JR, Lightman SL: Origin of ultradian pulsatility in the hypothalamic-pituitary-adrenal axis. Proc Bio/ Sci 2010, 277:1627-1633.

52. Walker JJ, Terry JR, Tsaneva-Atanasova K, Armstrong SP, McArdle CA, Lightman SL: Encoding and decoding mechanisms of pulsatile hormone secretion. J Neuroendocrinol 2010, 22:1226-1238.

53. Walker JJ, Spiga F, Waite E, Zhao Z, Kershaw Y, Terry JR, Lightman SL: The origin of glucocorticoid hormone oscillations. PLOS Biol 2012, 10:e1001341.

54. Schibler U, Sassone-Corsi P: A web of circadian pacemakers. Cell 2002, 111:919-922.

55. Takahashi JS, Hong HK, Ko CH, McDearmon EL: The genetics of mammalian circadian order and disorder: implications for physiology and disease. Nat Rev Genet 2008, 9:764-775.

56. Nader N, Chrousos GP, Kino T: Interactions of the circadian CLOCK system and the HPA axis. Trends Endocrinol Metab 2010, 21:277-286.

57. Nader N, Chrousos GP, Kino T: Circadian rhythm transcription factor CLOCK regulates the transcriptional activity of the glucocorticoid receptor by acetylating its hinge region lysine cluster: potential physiological implications. FASEB J 2009, 23:1572-1583.

58. Charmandari E, Chrousos GP, Lambrou Gl, Pavlaki A, Koide H, Ng SSM, Kino T: Peripheral CLOCK Regulates Target-Tissue Glucocorticoid Receptor Transcriptional Activity in a Circadian Fashion in Man. PLoS One 2011, 6:e25612.

59. Pavlatou MG, Vickers KC, Varma S, Malek R, Sampson M, Remaley AT, Gold PW, Skarulis MC, Kino T: Circulating cortisol-associated signature of glucocorticoid-related gene expression in subcutaneous fat of obese subjects. Obesity (Silver Spring) 2013, 21:960-967.

60. Lamia KA, Papp SJ, Yu RT, Barish GD, Uhlenhaut NH, Jonker JW, Downes N, Evans RM: Cryptochromes mediate rhythmic repression of the glucocorticoid receptor. Nature 2011, 480:552-556.

61. Han DH, Lee YJ, Kim K, Kim CJ, Cho S: Modulation of glucocorticoid receptor induction properties by core circadian clock proteins. Mol Cell Endocrinol 2014, 383:170-180.

62. Nicolaides NC, Charmandari E, Chrousos GP, Kino T: Circadian endocrine rhythms: the hypothalamic-pituitary-adrenal axis and its actions. Ann N Y Acad Sci 2014, 1318:71-80.

63. Kino T, Chrousos GP: Circadian CLOCK-Mediated Regulation of TargetTissue Sensitivity to Glucocorticoids: Implications for Cardiometabolic Diseases. Endocr Dev 2011, 20:116-126.

64. Ramamoorthy S, Cidlowski JA: Ligand-induced repression of the glucocorticoid receptor gene is mediated by an NCoR1 repression 
complex formed by long-range chromatin interactions with intragenic glucocorticoid response elements. Mol Cell Biol 2013, 33:1711-1722.

65. Weaver IC, Cervoni N, Champagne FA, D'Alessio AC, Sharma S, Seckl JR, Dymov S, Szyf M, Meaney MJ: Epigenetic programming by maternal behavior. Nat Neurosci 2004, 7:847-854.

66. Uchida S, Nishida A, Hara K, Kamemoto T, Suetsugi M, Fujimoto M Watanuki T, Wakabayashi Y, Otsuki K, McEwen BS, Watanabe Y: Characterization of the vulnerability to repeated stress in Fischer 344 rats: possible involvement of microRNA-mediated down-regulation of the glucocorticoid receptor. Eur I Neurosci 2008, 27:2250-2261

67. Vreugdenhil E, Verissimo CS, Mariman R, Kamphorst JT, Barbosa JS, Zweers T, Champagne DL, Schouten T, Meijer OC, de Kloet ER, Fitzsimons CP: MicroRNA 18 and 124a down-regulate the glucocorticoid receptor: implications for glucocorticoid responsiveness in the brain. Endocrinology 2009, 150:2220-2228.

68. Fitzsimons CP, van Hooijdonk LW, Schouten M, Zalachoras I, Brinks V, Zheng T, Schouten TG, Saaltink DJ, Dijkmans T, Steindler DA, Verhaagen J, Verbeek FJ, Lucassen PJ, de Kloet ER, Meijer OC, Karst H, Joels M, Oitzl MS, Vreugdenhil E: Knockdown of the glucocorticoid receptor alters functional integration of newborn neurons in the adult hippocampus and impairs fear-motivated behavior. Mol Psychiatry 2013, 18:993-1005.

69. Zalachoras I, Houtman R, Atucha E, Devos R, Tijssen AM, Hu P, Lockey PM, Datson NA, Belanoff JK, Lucassen PJ, Joëls M, de Kloet ER, Roozendaal B, Hunt $\mathrm{H}$, Meijer OC: Differential targeting of brain stress circuits with a selective glucocorticoid receptor modulator. Proc Natl Acad Sci U S A 2013, 110:7910-7915.

doi:10.1186/1472-6823-14-71

Cite this article as: Nicolaides et al:: Recent advances in the molecular mechanisms determining tissue sensitivity to glucocorticoids: novel mutations, circadian rhythm and ligand-induced repression of the human glucocorticoid receptor. BMC Endocrine Disorders 2014 14:71.

\section{Submit your next manuscript to BioMed Central and take full advantage of:}

- Convenient online submission

- Thorough peer review

- No space constraints or color figure charges

- Immediate publication on acceptance

- Inclusion in PubMed, CAS, Scopus and Google Scholar

- Research which is freely available for redistribution 